\title{
ANALISIS ICOR TERHADAP EFISIENSI PERTUMBUHAN EKONOMI DI PROVINSI PAPUA
}

\author{
Marsi Adi Purwadi1 \\ marsipurwadi@gmail.com
}

\author{
Fandini Diamona Jamaluddin ${ }^{2}$ \\ Jamaludin_fandini@gmail.com
}

\begin{abstract}
1Dosen Fakultas Ekonomi dan Bisnis Universitas Cenderawasih
2Mahasiswa Fakultas Ekonomi dan Bisnis Universitas Cenderawasih
\end{abstract}

\section{Abstraksi:}

Dalam perencanaan pembangunan ekonomi, target pertumbuhan ekonomi telah ditentukan sebelumnya, dimana salah satu faktor pendukung diantaranya ditentukan oleh investasi. Penelitian ini bertujuan untuk : 1) Menganalisis perkembangan ICOR Provinsi Papua pada tahun 2009-2019; 2) Menganalisis pengaruh ICOR terhadap pertumbuhan ekonomi Provinsi Papua pada tahun 2009-2019; dan 3) Mempercepat proses pencapaian pertumbuhan ekonomi melalui penyusunan strategi kebijakan investasi sektoral dan kewilayahan. Hasil penelitian ini menunjukan bahwa : Rasio ICOR tahun 2010 hingga 2019 mempunyai trend nilai positif, namun demikian terdapat nilai terendah ICOR sebesar minimum -1,75 yang merupakan koefisien ICOR di tahun 2019. Peningkatan PDRB di Provinsi Papua mengalami peningkatan yang fluktuatif, hal ini juga berpengaruh terhadap ICOR yang bernilai positif tidak signifikan. Semakin tinggi PDRB Provinsi Papua, maka investasi yang diberikan oleh pihak investor akan mengalami peningkatan namun peningkatannya tidak terlalu signifikan dalam perekonomian. Berdasarkan hasil analisis deskriptif kualitatif teridentifikasi beberapa faktor yang dapat mempengaruhi perkembangan investasi di Provinsi Papua yaitu : hak ulayat, izin pelepasan kawasan yang masih menjadi kewenangan pemerintah pusat, insentif fiskal, akses pengusaha UMKM terhadap modal, infrastruktur, tingkat kemahalan, sistem Tataran Transportasi Wilayah dan Tataran Transportasi Lokal, Ketersediaan tenaga kerja lokal yang terampil dan bependidikan, ketersediaan data potensi Papua yang akurat, birokrasi dalam pengurusan perizinan sektoral, pembinaan terhadap pengusaha-pengusaha lokal, dan pengembangan komoditi unggulan yang berbasis lahan masih mendominasi dalam perencanaan investasi, sehingga sering berbenturan dengan tata ruang wilayah.

Kata Kunci : ICOR, Efisiensi Pertumbuhan Ekonomi, dan Perencanaan.

\section{PENDAHULUAN}

Pertumbuhan ekonomi umumnya menyebabkan peningkatan standar hidup. Tetapi bagaimana pertumbuhan terutama pertumbuhan berkelanjutan diciptakan? Bagian ini berfokus pada pertumbuhan dari sudut pandang kawasan. Seperti yang akan kita lihat, perspektif kawasan dari pertumbuhan optimal atau kompleksitas dari satu perspektif ekonomi makro (Edwards, 2007). Pertumbuhan ekonomi juga merupakan faktor terpenting yang berkontribusi terhadap pengurangan kemiskinan (Nafziger, 2006).

Pembangunan ekonomi mengacu pada pertumbuhan ekonomi yang disertai dengan perubahan distribusi output dan struktur ekonomi. Perubahan ini mungkin termasuk peningkatan kesejahteraan materi dari separuh populasi yang lebih miskin (Nafziger, 2006). Mengingat pertumbuhan ekonomi dalam praktiknya diamati terkait erat dengan perubahan dalam struktur produksi, hal ini tentu saja mengurangi penerapan konsep pertumbuhan stabil di kehidupan nyata (Association \& Economic, 1965).

Investasi merupakan kegiatan yang membutuhkan waktu, dan kadang-kadang waktu yang dibutuhkan cukup lama. Dengan kata lain, hasil dari suatu investasi tidak dengan segera dapat dinikmati, oleh karena itu sinergi program dan kegiatan serta tersedianya aturan atau kebijakan dasar di Kabupaten Majalengka merupakan hal yang mutlak diperlukan untuk mewujudkan investasi yang telah dan akan dilakukan dimasa mendatang. Investasi juga menjadi salah satu faktor penting penentu keberhasilan pembangunan ekonomi daerah (L Suparto, 2017).

Pembentukan modal dan ICOR, rasio output modal tambahan, kebalikan dari rasio peningkatan output terhadap investasi, adalah variabel fundamental dalam model pertumbuhan Harrod-Domar (Nafziger, 2006). ICOR merupakan salah satu bagian dari statistik deskriptif yang dikembangkan secara khusus terkait dengan kajian investasi ekonomi makro (Masloman, 2020). ICOR merupakan kebutuhan investasi terhadap peningkatan 1 persen produk domestik bruto (PDB) (Ekonomi \& Borobudur, 2015). Sedangkan (L Suparto, 2017) menungkapkan bahwa semakin kecil koefisien ICOR menunjukkan semakin efisien pembentukan modal yang terjadi. Hal ini membuktikan bahwa pola hubungan yang negatif 
antara pertumbuhan ekonomi dan ICOR menunjukan semakin tinggi pertumbuhan ekonomi akan semakin rendah ICOR atau sebaliknya semakin rendah pertumbuhan ekonomi akan semakin tinggi ICOR (Suandi \& Delis, 2020).

Angka ICOR yang dianggap ideal (efisien) berada pada kisaran 3-4 (Suandi \& Delis, 2020). Susilowati et al., 2012, Hubungan antara pembentukan modal dan pertumbuhan output tercermin pada indikator makroekonomi yang dikenal sebagai ICOR (Incremental Capital Output Ratio). Indikator ini menunjukkan besarnya tambahan kapital baru yang dibutuhkan untuk meningkatkan satu unit output (atau nilai tambah). Semakin tinggi ICOR mengidentifikasikan kemungkinan terjadinya inefesiensi dalam penggunaan investasi. Sebaliknya, ICOR yang rendah menunjukkan adanya efisiensi dalam penggunaan modal (Munifah, 2019).

Pertumbuhan ekonomi sendiri tidak terlepas dari peran penanaman modal, modal merupakan suatu hal yang sangat penting bagi perekonomin suatu negara atau wilayah, penanaman modal dapat mempengaruhi tinggi rendahnya pembangunan dan pertumbuhan ekonomi suatu negara ataupun wilayah. Provinsi Papua merupakan salah satu Provinsi dengan share PDRB terendah terhadap pembentukan PDB nasional, hal ini tidak terlepas dari minimnya infastruktur dan kondisi geografis yang memaksa peran penanaman modal yang dilakukan oleh pemerintah belum memberika effect yang nyata, dalam penelitian ini penanaman modal yang dimaksud adalah Pembentukan Modal Tetap Bruto (PMTB). Bila dilihat dari penciptaan sumber pertumbuhan ekonomi triwulan I-2020 (y-on-y), Komponen PK-RT merupakan komponen dengan sumber pertumbuhan tertinggi, yakni sebesar 1,24 persen; diikuti Komponen Pembentukan Modal Tetap Bruto sebesar 0,63 persen dan Komponen PK-P sebesar 0,37 persen (Badan Pusat Statistik, 2020).

Bisa dikatakan bahwa investasi memiliki peran yang sangat penting dalam suatu perekonomian. Pentingnya investasi ini dapat ditinjau dari dua aspek. Pertama, karena investasi merupakan komponen yang besar dan volatile dari pengeluaran, investasi sering merujuk kepada perubahan dalam permintaan agregat sehingga mempengaruhi siklus bisnis. Kedua, investasi mengacu pada akumulasi modal. Dengan menambah persediaan bangunanbangunan dan peralatan, akan meningkatkan output potensial dan akan mendorong pertumbuhan ekonomi jangka panjang. Dengan demikian investasi memiliki dua peran, yaitu mempengaruhi output jangka pendek melalui pengaruhnya terhadap permintaan agregat dan mempengaruhi pertumbuhan output jangka panjang melalui pengaruhnya terhadap pembentukan modal pada output potensial dan penawaran agregat (Purwadi, Hafizrianda, Ayu, \& Riani, 2018).

Provinsi Papua merupakan salah satu provinsi yang memiliki nilai share PDRB terkecil diantara Provinsi lain di Indonesia sehingga membuat Provinsi Papua memiliki nilai PDRB terkecil diantara provinsi lain di Indonesia, hal ini membuat peneliti ingin menganalisis bagaimana tingkat efisiensi di Provinsi Papua dengan menggunakan ICOR sebagai proksi dari efisiensi penggunaan modal dan menganalisis pengaruh efisiensi terhadap pertumbuhan ekonomi Provinsi Papua.

Berdasarkan latar belakang penelitian tersebut di atas, maka tujuan penelitian ini adalah sebagai berikut : 1) Melihat perkembangan ICOR Provinsi Papua pada tahun 2010-2019; 2) Menganalisis pengaruh ICOR terhadap pertumbuhan ekonomi Provinsi Papua pada tahun 2010-2019; 3) Mempercepat proses pencapaian pertumbuhan ekonomi melalui penyusunan strategi kebijakan investasi sektoral dan kewilayahan

\section{METODE PENELITIAN}

\section{A. Ruang Lingkup Penelitiandan Obyek Penelitian}

Kegiatan penelitian ini dilakukan berdasarkan dua ruang lingkup, yaitu 1) ruang lingkup wilayah, dan 2) ruang lingkup materi. Pertama, ruang lingkup wilayah yang dimaksud dalam penelitian ini adalah 1) Pemerintah Provinsi Papua; dan 2) Instansi/Lembaga lainnya. Kedua, yang dimaksud dengan ruang lingkup penelitian materi yaitu: 1) analisis ekonomi makro pada tingkat regional, dan 2) teori pendukung dan penelitian tentang ekonomi regional.

Adapun objek dalam penelitian ini adalah : Pemerintah Provinsi Papua. Dimana dengan melakukan penelitian atas Pemerintah Provinsi Papua, maka akan ditemukan sebuah gambaran yang komprehensif tentang investasi dan pertumbuhan ekonomi di Provinsi Papua.

\section{B. Jenis dan Sumber Data}

Dalam penelitian ini, peneliti menggunakan pendekatan kuantitatif. Dimana pendekatan ini mengharuskan peneliti untuk mengumpulkan data yang diperoleh secara tidak langsung. Data sekunder sendiri merupakan data yang telah dikumpulkan oleh pihak lain, yang kemudian dikumpulkan oleh peneliti sebagai sumber data dan informasi. Metode 
pengumpulan data dalam penelitian ini adalah teknik dokumentasi, yaitu metode pengumpulan data utama melalui Instansi/Lembaga penyedia data, baik itu Instansi/Lembaga pemerintah maupun swasta. Sumber data dalam penelitian berasal dari instansi Badan Pusat Statistik, dan BKPM Papua, serta dari berbagai hasil penelitian yang memiliki hubungan erat dengan penelitian ini.

\section{Metode Analisis}

Dalam penelitian ini, penelitia akan menggunakan tida metode kuantitatif, dimana model-model yang digunakan ini merupakan model-model perencanaan pembangunan wilayah pada aspek makroregional. Adapun model-model yang dimaksud adalah ICOR dan Regresi sederhana. Sedangkan untuk analisis kualitatif menggunakan metode deskriptif kualitatif untuk menetapkan strategi kebijakan.

\section{ICOR Tenggang Waktu Satu Tahun}

Perkiraan ICOR dengan tenggang waktu satu tahun mengandung pengertian bahwa investasi yang dilakukan pada tahun $\mathrm{t}-1$ baru akan memberikan tambahan hasil pada tahun t. Perkiraan ICOR dengan tenggang waktu satu tahun dapat dihitung dengan rumus (Purwadi et al., 2018) :

$$
\begin{aligned}
& k_{t}=\frac{I_{i t-1}}{\Delta Y_{i t}}=\frac{\frac{I_{i t-1}}{Y_{i t-1}} x \mathbf{1 0 0}}{g_{i t}} \\
& \operatorname{dimana}_{k_{i t}} \quad \text { adalah ICOR pada tahun ke } t \text { untuk aktifitas } i \\
& l_{i t-1} \quad \text { adalah investasi pada tahun ke } t \text {-1 untuk aktifitas } i \\
& Y_{i t-1} \text { adalah pendapatan regional pada tahun ke } t-1 \text { untuk aktifitas } i \\
& g_{i t} \quad \text { adalah laju pertumbuhan aktifitas } i \text { pada tahun ke } t
\end{aligned}
$$

\section{E. Pengaruh ICOR terhadap Pertumbuhan Ekonomi}

Dalam mengukur hubungan antara ICOR dengan pertumbuhan ekonomi Provinsi Papua tahun 2010-2019, digunakan dengan pendekatan regresi linear sederhana. Regresi linier sederhana dapat digunakan untuk memprediksikan seberapa jauh perubahan nilai variabel dependen bila nilai variabel indepeden dirubah-rubah. Analisis regresi sederhana selain digunakan untuk mengukur kekuatan hubungan antara dua variabel, juga dapat menunjukkan arah hubungan antara variabel dependen dan variabel independen. Persamaan umum regresi linier sederhana dilakukan untuk mengetahui pengaruh Produk Domestik Regional Bruto (PDRB) terhadap Incremental Capital Output Ratio (ICOR), adapun rumus yang digunakan adalah sebagai berikut:

\section{ICORIndex $=\alpha+a X \operatorname{LnPDR} B+\varepsilon$}

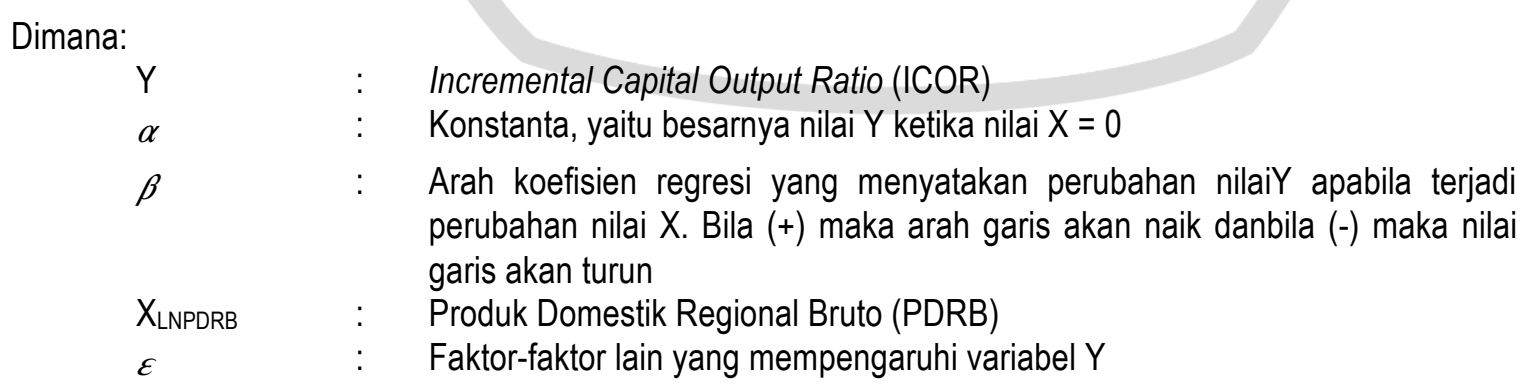




\section{F. Uji Statistik $\mathbf{t}$}

Uji statistik t menunjukkan seberapa jauh pengaruh satu variabel independen atau variabel penjelas secara individual dalam menerangkan variabel dependen (Ghozali, 2005). Apabila nilai probabilitas signifikansinya lebih kecil 0,05\% (5\%) maka suatu variabel independen berpengaruh signifikan terhadap variabel dependen. Hipotesis diterima jika taraf signifikan (a) $<0,05$ dan hipotesis ditolak jika taraf signifikan (a) $>0,05$.

Kriteria:

a. Jika t hitung $>\mathrm{t}$ tabel maka Ho ditolak dan Ha diterima.

b. Jika t hitung < t tabel maka Ho diterima dan Ha ditolak

Atau

a. Jika $p<0,05$, maka Ho ditolak dan Ha diterima

b. Jika $p>0,05$ maka Ho diterima dan Ha ditolak.

\section{G. Koefisien determinasi (R2)}

Koefisien determinasi (Goodness of fit), yang dinotasikan $\mathrm{R}^{2}$ merupakan suatu ukuran yang penting dalam regresi. Determinasi $\left(R^{2}\right)$ mencerminkan kemampuan variabel dependen. Tujuan analisis ini adalah untuk menghitung besarnya pengaruh variabel independen terhadap variabel dependen. Nilai $R^{2}$ menunjukkan seberapa besar proporsi dari total variasi variabel tidak bebas yang dapat dijelaskan oleh variabel penjelasnya. Semakin tinggi nilai $R^{2}$ menunjukkan seberapa besar proporsi dari total variasi variabel tidak bebas yang dapat dijelaskan oleh variabel penjelasnya. Semakin tinggi nilai $\mathrm{R}^{2}$ maka semakin besar proporsi dari total variasi variabel dependen yang dapat dijelaskan oleh variabel independen (Ghozali, 2005).

\section{HASIL DAN PEMBAHASAN}

\section{A. Analisis Incremental Capital Output Ratio (ICOR) Provinsi Papua tahun 2010-2019.}

ICOR adalah besaran yang menunjukkan besarnya tambahan kapital (investasi) yang dibutuhkan untuk menaikkan atau menambah satu unit output. Besaran ICOR dapat digunakan untuk memperkirakan besarnya kebutuhan investasi untuk mencapai target pertumbuhan yang ditetapkan pada masa yang akan datang. Selain itu besaran ICOR juga dapat digunakan untuk melihat produktifitas dan efisiensi dari investasi yang dilakukan. Semakin kecil nilai ICOR, semakin besar pula efisiensi dan produktifitas dari investasi yang ditanamkan sehingga dengan semakin efisien dan produktifnya investasi akan mengakibatkan pertumbuhan ekonomi.

ICOR (incremental capital output ratio) Jumlah tambahan modal yang dibutuhkan untuk meningkatkan output sebesar satu unit. Kebalikan dari rasio peningkatan output terhadap investasi, yang bersama-sama dengan tingkat investasi, menjelaskan tingkat pertumbuhan ekonomi (Nafziger, 2006). Sedangkan menurut Kuznets, rasio output modal tambahan (ICOR) telah memainkan peran penting dalam pertumbuhan ekonomi modern. (ICOR) mencerminkan produktivitas modal. Ini mengacu pada jumlah tambahan modal yang dibutuhkan untuk menghasilkan unit output tambahan (Jhingan, 1997).

Untuk melihat perkembangan ICOR di Provinsi Papua tahun 2010-2019 dapat dilihat pada tabel berikut:

\section{Tabel 1}

Perkembangan ICOR Provinsi Papua Tahun 2010-2019

\begin{tabular}{|l|l|l|l|l|}
\hline \multicolumn{1}{|c|}{ Tahun } & \multicolumn{1}{|c|}{$\begin{array}{c}\text { Investasi } \\
\text { (PMTB) }\end{array}$} & \multicolumn{1}{c|}{ PDRB } & \multicolumn{1}{c|}{ D PDRB } \\
\hline 2010 & $25,009,775.57$ & $110,808,176.61$ & $12,223,833.08$ & 2.05 \\
\hline 2011 & $27,037,628.81$ & $106,066,723.39$ & $-4,741,453.22$ & -5.70 \\
\hline 2012 & $28,882,224.98$ & $107,890,942.59$ & $1,824,219.20$ & 15.83 \\
\hline 2013 & $30,778,247.41$ & $117,118,818.90$ & $9,227,876.31$ & 3.34 \\
\hline 2014 & $33,168,025.96$ & $121,391,233.95$ & $4,272,415.05$ & 7.76 \\
\hline 2015 & $35,524,777.77$ & $130,311,604.86$ & $8,920,370.91$ & 3.98 \\
\hline 2016 & $37,824,226.82$ & $142,224,930.67$ & $11,913,325.81$ & 3.17 \\
\hline 2017 & $39,870,095.89$ & $148,818,289.86$ & $6,593,359.19$ & 6.05 \\
\hline 2018 & $42,576,324.45$ & $159,790,310.18$ & $10,972,020.32$ & 3.88 \\
\hline 2019 & $44,058,796.98$ & $134,677,637.74$ & $-25,112,672.44$ & -1.75 \\
\hline Rata-Rata ICOR & & & \\
\hline
\end{tabular}

Sumber: BPS Provinsi Papua, 2020 
Berdasarkan tabel di atas, diketahui bahwa perkembangan ICOR tertinggi di Provinsi Papua terjadi pada tahun 2012 yaitu sebesar 15,83\% artinya kategori perlu dipertimbangkan untuk mendapat prioritas investasi karena mempunyai multiplier effect yang relatif lebih luas. Selain itu, pilihan investasi juga harus mempertimbangkan kepemilikan sumber daya (resource endowments) dari daerah setempat, kebijakan pemerintah mengenai konservasi sumber daya alam, dan faktor lainnya. sedangkan perkembangan ICOR terendah terjadi pada tahun 2011 yaitu sebesar $-5,70 \%$ artinya bahwa kategori Isub kategori dengan koefisien ICOR kecil seharusnya mendapat prioritas untuk dilakukan investasi, karena dari segi ekonomi kategori ini menunjukkan tingkat efisiensi yang lebih tinggi. Rata-rata perkembangan ICOR di Provinsi Papua sepanjang tahun 2010-2019 adalah sebesar 3,86\% artinya setiap penambahan Rp.1 miliar output memerlukan investasi sebesar Rp. 3,86 miliar.

Kondisi ICOR Provinsi Papua diatas terjadi karena jumlah dan nilai investasi di Provinsi Papua yang selalu gerak fluktuatif, hal ini tentu saja akan berpengaruh terhadap pertumbuhan ekonomi di Provinsi Papua. Selain itu, minimnya Investasi juga dapat disebabkan oleh perilaku para investor. Dimana investor memiliki perhitungan sendiri dalam menentukan pilihan investasi, sedangkan pemerintah memiliki kewajiban untuk melakukan pemerataan pembangunan. Apabila masing-masing pihak saling menunggu, pembangunan kawasan industri di daerah yang sebenarnya sudah cukup layak menjadi terhambat atau kehilangan momentum yang baik (Pusat Pembinaan, Pendidikan, dan Pelatihan Perencana Nasional, 2018).

\section{B. Pengaruh ICOR terhadap pertumbuhan ekonomi Provinsi Papua pada tahun 2010-2019.}

Konsep ICOR pada awalnya dikembangkan oleh Sir Ray Harrod dan Evsey Domar yang lebih dikenal dengan HarrordDomar (dalam Arsyad, Lincolin. 1999), yang intinya menunjukkan adanya hubungan antara peningkatan stok kapasitas produksi dan kemampuan masyarakat untuk menghasilkan output. Harapannya adalah semakin tinggi peningkatan kapasitas produksi semakin tinggi pula output yang dapat dihasilkan. ICOR secara sederhana diartikan sebagai besaran yang menunjukkan banyaknya penambahan kapasitas produksi atau investasi yang dibutuhkan untuk dapat meningkatkan output sebanyak satu unit satuan. Atau secara matematis koefisisen ICOR dinyatakan sebagai rasio antara penambahan investasi $(\Delta \mathrm{l})$ terhadap penambahan output $(\Delta \mathrm{Y})$. Sebenarnya tambahan output tidak hanya dipengaruhi faktor investasi yang ditanamkan, akan tetapi juga dipengaruhi oleh variabel-variabel lainnya, seperti: pertumbuhan pada produktivitas, utilisasi kapasitas produksi. Faktor-faktor lain yang juga mempengaruhi investasi adalah IPM, PDRB dan tenaga kerja. Akan tetapi dalam penghitungan ICOR diasumsikan bahwa faktor-faktor lain tersebut dianggap konstan.

\section{Uji Koefisien Determinasi}

Uji koefisien determinasi bertujuan untuk mengukur garis regresi atau secara verbal mengukur proporsi total varians $Y$ yang dijelaskan oleh regresi. Sebelum mengukur koefisien determinasi terlebih dahulu harus menghitung koefisien korelsi (R). Penghitungan koefisien korelasi pada penelitian ini disajikan dalam tabel berikut ini:

Tabel 2
Model Summary
\begin{tabular}{|c|c|c|c|c|}
\hline \multirow{2}{*}{ Model } & $\mathrm{R}$ & $\mathrm{R}$ & Adjusted $\mathrm{R}$ & $\begin{array}{c}\text { Std. Error of the } \\
\text { Estimate }\end{array}$ \\
\hline 1 &, $351^{\mathrm{a}}$ & 0,123 & 0,014 & 1,91249 \\
\hline
\end{tabular}

a. Predictors: (Constant), LN_PDRB

b. Dependent Variable: ICOR

Sumber: data diolah, 2020

Berdasarkan tabel di atas, diketahui bahwa koefisien determinasi antara variabel PDRB dengan ICOR sebesar 0,123. Artinya terdapat hubungan yang erat antara variabel PDRB dengan ICOR. Hal ini dapat dijelaskan bahwa, variabel PDRB mampu menjelaskan pengaruh terhadap ICOR di Provinsi Papua sebesar 12,3\%, sedangkan sisanya sebesar $87,7 \%$ dipengaruhi oleh variabel lain yang tidak diteliti dalam penelitian ini.

2. Uji t

Uji hipotesis secara persial dengan uji t bertujuan untuk mengetahui dari masing-masing variabel bebas $X$ terhadap variabel terikat $y$. Pengujian dilakukan dengan membandingkan thitung dengan $t_{\text {tabel }}$ perhitungan nilai thitung dilakukan dengan menggunakn Sofware SPSS 21 of Windows. Hasil thitung disajikian dalam tabel 3. 
Tabel 3

Coefficientas*

Coefficients $^{\mathrm{a}}$

\begin{tabular}{|l|l|l|l|l|l|}
\hline \multirow{2}{*}{ Model } & \multicolumn{2}{|l|}{$\begin{array}{l}\text { Unstandardized } \\
\text { Coefficients }\end{array}$} & $\begin{array}{l}\text { Standardized } \\
\text { Coefficients }\end{array}$ & \multirow{2}{*}{$\mathrm{t}$} & \multirow{2}{*}{ Sig. } \\
\cline { 2 - 6 } & $\mathrm{B}$ & Std. Error & Beta & & \\
\hline 1. (Constant) & $-89,388$ & 83,746 & & $-1,067$ & 0,317 \\
\hline LN_PDRB & 4,762 & 4,488 & 0,351 & 1,061 & 0,32 \\
\hline
\end{tabular}

a. Dependent Variable: ICOR

Sumber: data diolah, 2020

Berdasarkan tabel 5.3 diatas maka dapat dibentuk persamaan regresi yang dapat digunakan untuk memprediksi pengaruh PDRB terhadap ICOR di Provinsi Papua sebagai berikut:

\section{$Y=-89,388+4,762$ LN_PDRB $++e$}

Model persamaan regresi berganda di atas bermakna:

Y $\quad$ : Nilai konstanta sebesar $\mathbf{- 8 9 , 3 8 8}$ artinya apabila variabel PDRB bernilai nol, maka ICOR memiliki nilai sebesar $-89,388$.

LN_PDRB $\quad$ : Variabel PDRB berpengaruh positif terhadap ICOR dengan nilai koefisien 4,762, artinya setiap pertambahan $1 \%$ variabel PDRB akan meningkatkan ICOR sebesar $\mathbf{4 , 7 6 2}$ rupiah dengan asumsi variabel lain dalam kondisi konstan.

Hasil pengujian secara parsial menunjukkan thitung untuk PDRB sebesar 1,061. Besarnya tabel pada $\alpha=0,05$ adalah sebesar 1,812. Besarnya thitung untuk IPM sebesar 1,061> dari tabel 1,812 dengan angka signifikansi sebesar 0,324 > 0,05. Dengan demikian dapat disimpulkan bahwa PDRB berpengaruh positif tetapi tidak signifikan terhadap ICOR di Provinsi Papua. Berdasarkan teorinya sendiri, Incremental Caapital Output Ratio (ICOR) memperlihatkan adanya kaitan jumlah kenaikan output $(\Delta \mathrm{Y})$ dikarenakan kenaikan tertentu stok modal $(\Delta \mathrm{K})$. Jika peningkatan stok modal meningkat maka akan meningkat juga output yang akan dihasilkan (Jhingan, 2000). Pentingnya COR dan ICOR akan teerlihat jika menguji konsistensi antara target pembangunan dengan tambahan modal yang dikumpulkan dari tabungan berjalan (Arsyad, 1999).

Peningkatan PDRB di Provinsi Papua mengalami peningkatan yang fluktuatif, hal ini juga berpengaruh terhadap ICOR yang bernilai positif tidak signifikan. Semakin tinggi PDRB Provinsi Papua, maka investasi yang diberikan oleh pihak investor akan mengalami peningkatan namun peningkatannya tidak terlalu signifikan dalam perekonomian. Namun demikian masa depan pembangunan ekonomi masih jauh dari jaminan bahwa banyak orang yang keluar dari kemiskinan tetap rentan, lingkungan alam yang memburuk, dan pertumbuhan ekonomi nasional tetap tidak pasti. Pembangunan ekonomi adalah sebuah proses, bukan bertahun-tahun, tetapi beberapa decade (Todaro \& Smith, 2015).

\section{Strategi Kebijakan Investasi Sektoral dan Kewilayahan}

\section{Strategi Peningkatan Investasi Di Provinsi Papua}

Berdasarkan hasil analisis dan penelahaan isu-isu strategis, maka dapat disusun beberapa strategi guna mewujudkan sasaran yang telah ditetapkan sebagai berikut :

1) Strategi pengembangan kawasan dan pusat-pusat pertumbuhan yang baru. Strategi ini dilaksanakan dengan meningkatkan pembangunan infrastruktur transportasi darat pada kawasan-kawasan sentra produksi yang potensial, dan menarik investor secara maksimal;

2) Strategi pengembangan transportasi terpadu. Strategi ini dilaksanakan dengan mengembangkan integrasi antara transportasi darat, laut dan udara, yang berguna untuk meningkatkan konektifitas antara tempat 
produksi dengan pengiriman bahan baku, serta tempat produksi dengan pasar. Selain itu juga memperkuat Tatrawil dan Tatralok;

3) Strategi optimalisasi potensi komoditi unggulan investasi berbasis tata ruang;

4) Strategi penguatan dan pengembangan kapasitas kelembagaan ekonomi, khususnya lembaga pasar, lembaga kemitraan (output dan input), dan kelompok kerja.

5) Strategi optimalisasi kepastian hukum dalam berinvestasi. Terutama untuk kepastian hukum mengenai pelepasan tanah adat, dan pengurusan sertfikat tanah;

6) Strategi peningkatan muatan lokal (local content) dalam setiap produk-produk investasi.

\section{Kebijakan Peningkatan Investasi di Provinsi Papua}

a) Kebijakan Umum

1) Optimalisasi sentra-sentra ekonomi baru/pesebaran investasi melalui pendekatan Kawasan Ekonomi Khusus (KEK) dengan ketersediaan infrastruktur yang terjamin.

2) Pengembangan industrialisasi skala besar dangan pendekatan klaster industry berbasis wilayah Adat.

3) Pemetaan lokasi pengembangan klaster industri termasuk penyediaan infrastruktur keras (hard infrastructure) dan infrastruktur lunak (soft infrastructure) yang mencukupi termasuk pemberian kemudahan penanaman modal

4) Pemetaan potensi sumber daya dan rantai nilai (value chain) distribusi untuk mendukung pengembangan klaster-klaster industri dan pengembangan ekonomi daerah berbasis wilayah Adat.

b) Kebijakan Bidang Pertanian \& Perkebunan

1) Pengembangan tanaman pertanian perkebunan yang bersifat intensifikasi dengan produk utama untuk agroindustry (Sektor pertanian khususnya komoditi jagung, ubi kayu, kacang tanah, padi)

2) Pengembangan klaster komoditi unggulan yang berdaya saing berbasis wilayah Adat.

3) Peningkatan penggunaan teknologi tepat guna dan berwawasan lingkungan dalam pengembangan sektor pertanian dan perkebunan.

c) Kebijakan Bidang Perikanan

1) Pengembangan sumber daya manusia bidang pariwisata untuk mendukung pembangunan sektor pariwisata yang kreatif dan berdaya saing.

2) Pengembangan klaster komoditi unggulan perikanan yang berdaya saing berbasis wilayah Adat.

3) Peningkatan penelitian bidang perikanan untuk menghasilkan komoditi sektor perikanan yang mampu memenuhi pasar daerah maupun nasional

4) Peningkatan penggunaan teknologi tepat guna dan berwawasan lingkungan dalam pengembangan sektor perikanan.

d) Kebijakan Bidang Peternakan

1) Pengembangan sumber daya manusia bidang peternakan untuk mendukung pembangunan sektor peternakan berbasis teknologi tepat guna.

2) Pengoptimalan klaster komoditi unggulan sktor peternakan (sapi, kambing dan babi) yang berdaya saing berbasis wilayah Adat.

3) Peningkatan penelitian bidang peternakan untuk menghasilkan komoditi sektor peternakan yang mampu memenuhi pasar daerah maupun nasional

4) Peningkatan penggunaan teknologi tepat guna dan berwawasan lingkungan dalam pengembangan sektor peternakan.

e) Kebijakan Bidang Kehutanan

1) Pengembangan sumber daya manusia bidang kehutanan untuk mendukung pembangunan sektor kehutanan yang berkelanjutan.

2) Meningkatkan koordinasi dengan Dinas Kehutanan Provinsi Papua alam upaya pemetaan hutan produksi yang layak untuk diinvestasikan

3) Peningkatan dan pengoptimalan penggunaan teknologi yang ramah lingkungan dan terintegrasi dari hulu ke hilir 
4) Peningkatan kegiatan penelitian dan meningkatkan citra sektor kehutanan kabupaten/Kotayang berbasis keberlanjutan

f) Kebijakan Bidang Pertambangan dan Energi

1) Optimalisasi potensi dan sumber energi baru dan terbarukan serta penyiapan pembangunan infrastuktur dalam mendukung diversivikasi sumber energi pada industri-industri yang ada guna mendorong tumbuhnya kawasan industry berbasis wilayah Adat.

2) Peningkatan kegiatan penelitian dan meningkatkan citra pertambangan energi Kabupaten/kota yang berbasis teknologi dan inovasi

3) Terbangunnya pembangkit listrik yang memiliki kapasitas optimal dalam mendukung pengembangan investasi daerah berbasis wilayah Adat.

4) Prioritas kepada peningkatan Kerjasama Pemerintah-Swasta (KPS) dalam pembangunan pembangkit energi untuk industri dan sumber energi terbarukan.

g) Kebijakan Bidang Pariwisata

1) Pengembangan sumber daya manusia bidang pariwisata untuk mendukung pembangunan sektor pariwisata yang kreatif dan berdaya saing berbasis wilayah Adat.

2) Pengembangan destinasi wisata daerah yang memiliki daya tarik berbeda dengan wilayah/daerah lain di Indonesia

3) Pengkajian penyiapan readiness criteria infrastruktur

4) Peningkatan kegiatan ekonomi berbasis klaster industri pariwisata berbasis wilayah Adat.

5) Peningkatan kerjasama pemerintah dan swasta untuk pengembangan pariwisata yang berbasis iptek dan bersifat massal tanpa meninggalkan pariwisata berbasis alam

h) Kebijakan Bidang Perdagangan dan Jasa

1) Pengoptimalan dan pengembangan kegiatan perdagangan yang bersifat intensifikasi yang memiliki keterkaikan besar ke depan (forward lingkage) dan kebelakang (backward lingkage) berbasis wilayah Adat.

2) Peningkatan dan pengoptimalan penggunaan teknologi kegiatan perdagangan yang ramah lingkungan dan terintegrasi dari hulu ke hilir

3) Pengembangan sektor perdagangan dan dengan skala besar, mempercepat distribusi barang dan jasa, energi terbarukan yang berbasis pada pengetahuan dan teknologi.

i) Kebijakan Bidang Infrastruktur

1) Pengembangan Kerjasama Pemerintah-Swasta (KPS) dalam penyediaan infrastruktur strategis daerah

2) Mengintensifkan pembebasan lahan untuk pengembangan infrastruktur.

3) Pengembangan infrastruktur strategis (jalan, jembatan, pelabuhan, listrik, air) pendukung sektor unggulan (industri, pertanian) dan wilayah persebarannya

4) Pengembangan sektor strategis pendukung pengembangan infrastruktur seperti Industri transportasi, perdagangan berbasis wilayah Adat

5) Peningkatan penggunaan teknologi infrastruktur yang ramah ingkungan dan menciptakan keterkaitan yang luas (spread) Multiplier effek yang besar

6) Tersedianya infrastruktur keras (hard infrastructur) dan infrastruktur lunak (soft infrastructur) berskala besar yang dapat memenuhi kebutuhan industri Kabupaten/Kota yang berbasis pengetahuan dan teknologi.

7) Pengembangan infrastruktur yang dapat menopang kawasan-kawasan sentra produksi dan Kawasan industry.

j) Kebijakan Bidang Industri

1) Pengembangan Kerjasama Pemerintah-Swasta (KPS) dalam penyediaan infrastruktur Kawasan Industri

2) Pengembangan hulu-hilir industry berbasis sumber daya alam berbasis wilayah Adat

3) Identifikasi industri-industri pengolah bahan mentah menjadi bahan baku dan wilayah pesebarannya

4) Pengembangan tanaman perkebunan, pertanian, perikanan, peternakan, kehutanan dan pariwisata berskala besar (food and cpo estate) pada wilayah sentra-sentra pengembangan produk Kabupaten/Kota yang berbasis pengetahuan dan teknologi.

5) Implementasi persaingan usaha yang sehat dan terlaksanya hubungan industrial yang harmonis.

6) Pengembangan ekonomi berbasis pengetahuan (knowledge-based economy) pada industri berbasis agroindustri terpadu berbasis wilayah Adat 
7) Menumbuh kembangkan kolaborasi pengembangan klaster industri pariwisata dan industri berbasis agro berbasis wilayah Adat

8) Mengembangkan klaster industri pariwisata dan klaster industri berbasis agro yang berwawasan lingkungan dan berstandar internasional

k) Kebijakan bidang UMKMK

1) Memutakhirkan data UMKMK yang potensial di Kabupaten/kota untuk ditawarkan kerjasama dengan usaha besar PMDN dan PMA

2) Pengoptimalan kapasitas SDM UMKMK pada aspek teknis, inovasi dan manajemen

3) Memfasilitasi UMKMK untuk pengenalan dan pemesaran produk pada kegiatan promosi, expo, temu usaha, dII

4) Penguatan peran serta masyarakat dalam pengelolaan sumber daya ekonomi yang dimanfaatkan oleh UMKMK

5) Membangun dan mengembangkan kerjasama internasional antara penghasil iptek dengan UMKMK dan usahawan teknologi baru.

6) Memperkuat kelembagaan pusat inovasi untuk pengembangan UMKMK dan usahawan teknologi baru.

\section{Program-Program Prioritas}

Adapun program-program prioritas dalam kebijakan percepatan investasi di Provinsi Papua, sebagai berikut:

- Program Pemberdayaan Usaha Menengah, Usaha Kecil, Dan Usaha Mikro (UMKM)

Kegiatan : Pemberdayaan Usaha Mikro yang Dilakukan Melalui Pendataan, Kemitraan, Kemudahan Perijinan, Penguatan Kelembagaan dan Koordinasi dengan Para Pemangku Kepentingan. Sub Kegiatan : 1) Pendataan Potensi dan Pengembangan Usaha Mikro; 2) Pemberdayaan Melalui Kemitraan Usaha Mikro; 3) Fasilitasi Kemudahan Perizinan Usaha Mikro; 4) Pemberdayaan Kelembagaan Potensi dan Pengembangan Usaha Mikro; dan 5) Koordinasi dan Sinkronisasi dengan Para Pemangku Kepentingan dalam Pemberdayaan Usaha Mikro

- Program Pengembangan UMKM

Kegiatan : Pengembangan Usaha Mikro dengan Orientasi Peningkatan Skala Usaha Menjadi Usaha Kecil. Sub Kegiatan: Fasilitasi Usaha mikro Menjadi Usaha kecil dalam Pengembangan Produksi dan Pengolahan, Pemasaran, SDM, serta Desain dan Teknologi

- Program Pengembangan Iklim Penanaman Modal

Kegiatan : Penetapan Pemberian Fasilitas/Insentif Dibidang Penanaman Modal yang Menjadi Kewenangan Daerah Kabupaten/Kota. Sub Kegiatan : 1) Penetapan Kebijakan Daerah Mengenai Pemberian Fasilitas/Insentif dan Kemudahan Penanaman Modal; 2) Evaluasi Pelaksanaan Pemberian Fasilitas/Insentif dan Kemudahan Penanaman Modal

Kegiatan : Pembuatan Peta Potensi Investasi Kabupaten/Kota Sub Kegiatan : 1) Penyusunan Rencana Umum Penanaman Modal Daerah Kabupaten/Kota; dan 2) Penyediaan Peta Potensi dan Peluang Usaha Kabupaten/Kota

- Program Promosi Penanaman Modal

Kegiatan : Penyelenggaraan Promosi Penanaman Modal yang Menjadi Kewenangan Daerah Kabupaten/ Kota. Sub Kegiatan : 1) Penyusunan Strategi Promosi Penanaman Modal; dan 2) Pelaksanaan Kegiatan Promosi Penanaman Modal Daerah Kabupaten/Kota

- Program Pelayanan Penanaman Modal

Kegiatan : Pelayanan Perizinan dan Nonperizinan Secara Terpadu Satu Pintu Dibidang Penanaman Modal yang Menjadi Kewenangan Daerah Kabupaten/ Kota. Sub Kegiatan : 1) Penyediaan Pelayanan Terpadu Perizinan dan Nonperizinan berbasis Sistem Pelayanan Perizinan Berusaha Terintegrasi secara Elektronik; 2) Pemantauan Pemenuhan Komitmen Perizinan dan Nonperizinan Penanaman Modal; 3) Penyediaan Layanan Konsultasi dan Pengelolaan Pengaduan Masyarakat terhadap Pelayanan Terpadu Perizinan dan Nonperizinan; dan 4) Koordinasi dan Sinkronisasi Penetapan pemberian Fasilitas/Insentif Daerah

- Program Pengendalian Pelaksanaan Penanaman Modal

Kegiatan : Pengendalian Pelaksanaan Penanaman Modal yang Menjadi Kewenangan Daerah Kabupaten/Kota. Sub Kegiatan : 1) Koordinasi dan Sinkronisasi Pemantauan Pelaksanaan Penanaman 
Modal; 2) Koordinasi dan Sinkronisasi Pembinaan Pelaksanaan Penanaman Modal; dan 3) Koordinasi dan Sinkronisasi Pengawasan Pelaksanaan Penanaman Modal

- Program Pengelolaan Data Dan Sistem Informasi Penanaman Modal

Kegiatan : Pengelolaan Data dan Informasi Perizinan dan Nonperizinan yang Terintergrasi Pada Tingkat Daerah Kabupaten/Kota. Sub Kegiatan : Pengolahan, Penyajian dan Pemanfaatan Data dan Informasi Perizinan dan Nonperizinan berbasis Sistem Pelayanan Perizinan Berusaha Terintegrasi secara Elektronik.

\section{PENUTUP}

\section{A. Simpulan}

Berdasarkan hasil penelitian yang telah diuraikan di atas, penulis menarik kesimpulan sebagai berikut:

1. Rasio ICOR tahun 2010 hingga 2019 mempunyai trend nilai positif, namun demikian terdapat nilai terendah ICOR sebesar minimum -1,75 yang merupakan koefisien ICOR di tahun 2019. Kondisi ini sendiri terjadi disebabkan oleh terjadinya pertumbuhan ekonomi yang tinggi namun dilain sisi terjadi penurununan yang signifikan pada realisasi investasi PMA dan PMDN. Hal ini menunjukan bahwa seluruh sektor dalam perekonomian telah bekerja dengan optimal, walaupun disisi investasi tidak memberikan dorongan yang kuat. Dengan demikian dapat ditarik sebuah kesimpulan bahwa factor utama dalam penggerak pertumbuhan ekonomi di Provinsi Papua pada tahun 2010-2019 adalah konsumsi masyarakat, pengeluran pemerintah, dan ekspor-impor.

2. Peningkatan PDRB di Provinsi Papua mengalami peningkatan yang fluktuatif, hal ini juga berpengaruh terhadap ICOR yang bernilai positif tidak signifikan. Semakin tinggi PDRB Provinsi Papua, maka investasi yang diberikan oleh pihak investor akan mengalami peningkatan namun peningkatannya tidak terlalu signifikan dalam perekonomian. Jika peningkatan stok modal meningkat maka akan meningkat juga output yang akan dihasilkan, selain itu pentingnya COR dan ICOR akan teerlihat jika menguji konsistensi antara target pembangunan dengan tambahan modal yang dikumpulkan dari tabungan berjalan.

3. Berdasarkan hasil analisis deskriptif kualitatif teridentifikasi beberapa faktor yang dapat mempengaruhi perkembangan investasi di Provinsi Papua yaitu : hak ulayat, izin pelepasan kawasan yang masih menjadi kewenangan pemerintah pusat, insentif fiskal, akses pengusaha UMKM terhadap modal, infrastruktur, tingkat kemahalan, sistem Tataran Transportasi Wilayah dan Tataran Transportasi Lokal, Ketersediaan tenaga kerja lokal yang terampil dan bependidikan, ketersediaan data potensi Papua yang akurat, birokrasi dalam pengurusan perizinan sektoral, pembinaan terhadap pengusaha-pengusaha lokal, dan pengembangan komoditi unggulan yang berbasis lahan masih mendominasi dalam perencanaan investasi, sehingga sering berbenturan dengan tata ruang wilayah.

\section{B. Rekomendasi}

Berdasarkan kesimpulan dari hasil penelitian ini, maka penulis memberikan beberapa rekomendasi bagi Pemerintah

Provinsi Papua sebagai upaya perecepatan pengembangan investasi sebagai berikut:

1. Setiap daerah kabupaten/kota yang teridentifikasi tidak efisien untuk berinvestasi perlu mengendalikan angka ICOR-nya untuk berada pada interval angka yang moderat, dimana hal ini dapat dilakukan dengan cara menekan high cost to investment seoptimal mungkin, sehingga mampu meningkatkan gairah investasi bagi para pemilik modal.

2. Demikian juga untuk beberapa sektor ekonomi yang tidak efisien diperlukan kebijakan-kebijakan sektoral yang efektif guna mengatasi berbagai kendala investasi yang dapat mengurangi daya saing Provinsi Papua seperti mengatasi kendala hak ulayat, infrastruktur yang kurang memadai, akses modal dan pasar yang rendah, dan kualitas tenaga kerja lokal yang belum sesuai dengan kebutuhan pasar.

3. Optimalisasi pemanfaatan tata ruang wilayah pada 29 kabupaten/kota dengan mengubah paradigma investasi berbasis lahan menjadi investasi berbasis tata ruang dengan mengoptimalkan ruang yang tersedia tanpa melanggar ketetapan penggunaan yang berlaku. Hal ini dapat dilakukan dengan melakukan berbagai inovasi dalam kegiatan-kegiatan investasi sektoral seperti pengembangan investasi di sektor industri kreatif, pariwisata, tanaman hidroponik, penggunaan bibit unggul, dan sebagainya.

4. Meningkatkan daya saing penanaman modal melalui peningkatan kualitas dan mutu pelayanan penanaman modal 
5. Melakukan kerjasama dengan perguruan tinggi untuk penyediaan dan pengembangan sumber daya manusia yang handal dan memiliki ketrampilan (talent worker).

6. Mengembangkan system persaingan usaha yang sehat dan terlaksanya hubungan industrial yang harmonis.

7. Optimalisasi sentra-sentra ekonomi baru/pesebaran investasi melalui pendekatan Kawasan Ekonomi Khusus (KEK) dengan ketersediaan infrastruktur yang terjamin.

8. Pemberian fasilitas, kemudahan, dan atau insentif penanaman modal yang menjadi kewenangan Pemerintah Kabupaten seperti: keringanan Pajak Kenderaan Bermotor untuk bidang usaha tertentu pada kawasan tertentu; pengurangan atau pembebasan retribusi daerah

9. Pengembangan industrialisasi skala besar dangan pendekatan klaster industri

10. Pemetaan dan optimalisasi lokasi pengembangan klaster industri termasuk penyediaan infrastruktur keras (hard infrastructure) dan infrastruktur lunak (soft infrastructure) yang mencukupi termasuk pemberian kemudahan penanaman modal

11. Pemetaan potensi sumber daya dan rantai nilai (value chain) distribusi untuk mendukung pengembangan klaster-klaster industri dan pengembangan ekonomi daerah

12. Melakukan koordinasi dengan BPMPTSP Provinsi Papua dan BKPM Nasional untuk upaya-upaya percepatan pembangunan daerah melalui penanaman modal.

13. Melakukan koordinasi dan singkronisasi dengan pemerintah daerah yang berbatasan langsung dengan Kabupaten/kota untuk meningkatkan peluang kerjasama dan peluang penciptaan penanaman modal.

\section{DAFTAR PUSTAKA}

[1]. Aliansyah Teuku dkk. 2012. Pengaruh Dimensi Kualitas Pelayanan Terhadap Kepuasan Nasabah Bank Aceh Syariah. PP.1-9 Vol,1No,1 Aceh.

[2]. Association, T. A. E., \& Economic, T. R. S. (1965). Survey Of Economic Theory (Growth And Development) (Volume li). The Macmillan Press Ltd.

[3]. Badan Pusat Statistik. (2020). Pertumbuhan Ekonomi Papua Triwulan I-2020. Badan Pusat Statistik Provinsi Papua, Pp. 1-12. Retrieved From Https://Papua.Bps.Go.Id/Pressrelease/2020/05/05/485/Pertumbuhan-Ekonomi-Papua-Triwulan-I-2020.Html

[4]. Edwards, M. E. (2007). Regional And Urban Economics And Economic Development (Theory And Methods). Lixington, Kentucky: Auerbach Publications.

[5]. Ekonomi, J., \& Borobudur, U. (2015). Pengaruh Faktor-Faktor Inflasi Terhadap Investasi Asing Langsung Dan Pengangguran Serta Dampaknya Kepada Daya Beli Masyarakat Di Indonesia Oleh : Fransisca Sestri *), 17.

[6]. Jhingan, M. L. (1997). The Economics Of Development And Planning (40th Revis). Vrinda Publications (P) Ltd.

[7]. L Suparto, L. (2017). Maksi Jurnal Ilmiah Manajemen \& Akuntansi. Maksi Jurnal IImiah Manajemen \& Akuntansi, 4, 64-54.

[8]. Masloman, I. (2020). Analisa Perhitungan Icor Di Kabupaten Minahasa Tengga. Jurnal Berkala IImiah Efisiensi, 20(02), $12-20$.

[9]. Munifah, S. (2019). Analisis Icor Terhadap Efisiensi Pertumbuhan Ekonomi Di Indonesia. Universitas Muhammadiyah Surakarta.

[10]. Nafziger, E. W. (2006). Economic Development (Fourth Edi). New York: Cambridge University Press.

[11]. Purwadi, M. A., Hafizrianda, Y., Ayu, I., \& Riani, P. (2018). Target Pertumbuhan Investasi Dan Rencana Strategi Pengembangan Investasi Provinsi Papua. Keuda (Jurnal Kajian Ekonomi Dan Keuangan Daerah), 3(No.2), 13-42. Https://Doi.Org/Https://Doi.Org/10.31957/Keuda.V3i2.706

[12]. Pusat Pembinaan, Pendidikan, Dan Pelatihan Perencana Nasional, B. P. P. (2018). Kebijakan Publik Dan Studi Pembangunan. (Guspika, W. Adiyoso, W. Adiyoso, A. Muharram., R. Miranda, \& W. Witarni, Eds.) (Cetakan I,). Jakarta Pusat: Pusat Pembinaan, Pendidikan, Dan Pelatihan Perencana Nasional, Badan Perencanaan Pembangunan.

[13]. Suandi, \& Delis, A. (2020). Analysis Of Investment And Agricultural Sector Contributions To The Economy Of Merangin Jambi Province Using Icor Approaches. Jurnal Sosial Ekonomi Pertanian, 13(2), 112-124.

[14]. Susilowati, S. H., Hadi, P. U., Friyatno, S., Rachmat, M., Maulana, M., \& Azis, M. (2012). Estimation Of Incremental Capital Output Ratio ( Icor ) For Investment Planning In The Agricultural Sector Development Framework. Jurnal Agro Ekonomi, 30(2), 159-182.

[15]. Todaro, M. P., \& Smith, S. C. (2015). Economic Development. (D. Alexander, Ed.) (12th Editi). New York: Pearson. Retrieved From Www.Pearsonhighered.Com 